\title{
On the use of $\mathrm{TiC}$ as high-temperature healing particles in alumina based composites
}

\author{
Shunsuke Yoshioka¹, Linda Boatemaa², Sybrand van der Zwaag³ ${ }^{3}$ Wataru Nakao', Willem G. Sloof². \\ 1 Graduate School of Engineering, Yokohama National University, 79-5, Tokiwadai, Hodogaya-ku, Yokohama 240-8501, Japan \\ 2 Department of Material Science and Engineering, Delft University of Technology, Mekelweg 2, 2628 CD Delft, The Netherlands \\ 3 Facultv of Aerosnace Enaineerina. Delft Universitv of Technoloav. Kluvverwea 1. 2629 HS. Delft. The Netherlands \\ ${ }^{4}$ Faculty of Engineering, Yokohama National University, 79-5, Tokiwadai, Hodogaya-ku, Yokohama 240-8501, Japan
}

\begin{abstract}
We report on the use of TiC particles as high temperature healing agent in alumina based composites. The selection of TiC was based on a theoretical analysis of its high temperature stability in contact with $\mathrm{Al}_{2} \mathrm{O}_{3}$, its volumetric expansion upon oxidation and the adhesion between the reaction product $\mathrm{TiO}_{2}$ with $\mathrm{Al}_{2} \mathrm{O}_{3}$. Fully dense 15 and 30 volume percent TiC-Alumina composites were made by Spark Plasma Sintering. Initial damage was produced by Vickers indentations. The strength recovery was determined for temperatures between 400 and $800{ }^{\circ} \mathrm{C}$. The mechanical measurements were complemented by microstructural characterization of the base material and the healed cracks.
\end{abstract}

\section{Introduction}

In recent years there has been a lot of research into the autonomous healing of surface cracks in ceramics [1-23] and metallo-ceramics (MAX phase materials) [24-32] by oxidative filling of cracks when exposed to high temperatures. In the case of metallo-ceramics the healing is of the so-called intrinsic self healing type $[33,34]$, meaning that the metallo-ceramic itself is capable of undergoing 
an oxidative reaction resulting in filling of the crack and partial or complete recovery of the tensile strength. In the case of oxidic ceramics, such a reaction is impossible as the matrix is already in its oxidized state and cannot undergo any further reaction. Hence, for such materials the ability to heal surface cracks relies on the presence of intentionally embedded discrete particles called 'healing agents' which show a desirable response to high temperature exposure to oxygen containing gasses. Earlier works on such extrinsic healing ceramic systems focused on the oxidation of granular $\mathrm{SiC}$ particles embedded in several oxidic ceramic matrices. Harmer et al. observed that indentation induced cracks in alumina/ 5 -vol.\% SiC could be healed partially by means of annealing at $1300{ }^{\circ} \mathrm{C}$ for $2 \mathrm{~h} \mathrm{[1-2].} \mathrm{However,} \mathrm{they} \mathrm{also} \mathrm{noted} \mathrm{that} \mathrm{the} \mathrm{formed} \mathrm{SiO}_{2}$ could not seal the pre-cracks fully due to the low SiC particle content. Ando et al. were the first to report in detail on the self-healing behaviour of $\mathrm{SiC}$ particles containing alumina matrix composites as a function of temperature and annealing time [3-5]. It was shown that alumina/ 15 vol.\%-SiC composites can attain a complete strength recovery by annealing in air at $1300{ }^{\circ} \mathrm{C}$ for $1 \mathrm{~h}$ or at $1200{ }^{\circ} \mathrm{C}$ for $10 \mathrm{~h}$ [3]. Ando et al. demonstrated that other structural ceramic matrix composites containing SiC particles as self-healing agent, such as mullite/ $\mathrm{SiC}$ [6-7], $\mathrm{Si}_{3} \mathrm{~N}_{4} / \mathrm{SiC}$ [8-9], $\mathrm{ZrO}_{2} / \mathrm{SiC}$ [10-11], also show self-healing behaviour. They demonstrated that mullite-based composites containing 20 vol.\% of $\mathrm{SiC}$ particles could achieve complete strength recovery by various heat treatments at rather high temperatures, such as annealing for $5 \mathrm{~h}$ at $1200{ }^{\circ} \mathrm{C}$ or for $1 \mathrm{~h}$ at $1300{ }^{\circ} \mathrm{C}$ [7]. On the other hand, $\mathrm{Si}_{3} \mathrm{~N}_{4} / 20$ vol.\%-SiC and $\mathrm{ZrO}_{2} / 20 \mathrm{vol} . \%-\mathrm{SiC}$ composites recovered their room-temperature strength by annealing at relatively low temperatures e.g. at $1000{ }^{\circ} \mathrm{C}$ for $1 \mathrm{~h}$ in $\mathrm{Si}_{3} \mathrm{~N}_{4} / \mathrm{SiC}$ [9] and at $800{ }^{\circ} \mathrm{C}$ for 
$30 \mathrm{~h}$ in $\mathrm{ZrO}_{2} / \mathrm{SiC}$ composite [10], respectively. However, it was also observed that $\mathrm{Si}_{3} \mathrm{~N}_{4} / \mathrm{SiC}$ specimens annealed above $1400{ }^{\circ} \mathrm{C}$ and $\mathrm{ZrO}_{2} / \mathrm{SiC}$ specimens annealed above $1000{ }^{\circ} \mathrm{C}$ lose their mechanical properties due to excessive corrosion. In general, relatively high annealing temperatures (mostly above $1200^{\circ} \mathrm{C}$ ) are required for adequate oxidation of $\mathrm{SiC}$ particles in order to seal the crack-gap and to recover mechanical integrity of ceramics matrix composites.

Several methodologies have been proposed with the aim of enhancing the crack-healing ability of $\mathrm{SiC}$ containing composites. The first attempt involved the inclusion of $\mathrm{SiC}$ whiskers in order to simultaneously improve the fracture toughness, $K_{1,1}$ and self-healing ability of the composite [12-15]. Nakao et al. [12] observed that the $K_{\mathrm{IC}}$ value of 20 vol.\% SiC-whisker containing alumina based composites $\left(K_{\mathrm{IC}}=5.6-5.7 \pm 0.2 \mathrm{MPa} \cdot \mathrm{m}^{1 / 2}\right)$ is considerably higher than that of monolithic alumina $\left(K_{\mathrm{IC}}=3-4 \mathrm{MPa} \cdot \mathrm{m}^{1 / 2}\right)$. Furthermore, it was found for alumina with $20 \mathrm{vol} . \%-\mathrm{SiC}$ whisker that the minimum healing temperature at which the strength of the composite can recover within $1 \mathrm{~h}$ is $100{ }^{\circ} \mathrm{C}$ lower than that of alumina/ granular SiC composites. The effect was attributed to the larger surface area of the $\mathrm{SiC}$ whiskers per unit of volume. An alternative method to enhance the healing ability is downsizing of the healing agent [16-17]. Nakao et al. reported that alumina composite containing 18 vol.\% of nano-SiC having a diameter of $10-30 \mathrm{~nm}$ can attain full strength recovery within $10 \mathrm{~h}$ annealing at $950{ }^{\circ} \mathrm{C}$ [17]. So, depending on the morphology and size of the SiC fraction the minimum required temperature for the complete strength recovery can be varied in range of $950-1300{ }^{\circ} \mathrm{C}$.

More recently, some advanced healing agents replacing SiC have been proposed. Abe et al. 
developed alumina/ 10 vol.\%-NiAl composites which can heal cracks within $10 \mathrm{~h}$ in $1250{ }^{\circ} \mathrm{C}$ [18].

Nanko et al. proposed the use of nano-Ni powder as healing agents [19-21] and Maruoka et al. observed that alumina/ 5 vol.\%-nano Ni composites can attain full strength recovery by annealing for $1 \mathrm{~h}$ at $1200{ }^{\circ} \mathrm{C}$ [21]. In order to achieve full healing at lower temperatures, Ti containing self-healing agents have been proposed. For example, mullite with 15 vol.\%-TiSi 2 composites can achieve full strength recovery by annealing at $600{ }^{\circ} \mathrm{C}$ for $10 \mathrm{~h}$ [22]. The potential of Ti containing MAX phase, $\mathrm{Ti}_{2} \mathrm{Al}_{0.5} \mathrm{Sn}_{0.5} \mathrm{C}$, as healing agent has been studied by Bei et al. and they found that alumina with 20 vol.\%- $\mathrm{Ti}_{2} \mathrm{Al}_{0.5} \mathrm{Sn}_{0.5} \mathrm{C}$ composites can recover their strength fully by annealing for 5 h at $900{ }^{\circ} \mathrm{C}[23]$.

A potentially interesting self-healing system not yet studied in any detail is presented by alumina composites containing $\mathrm{TiC}$ particles as the healing agent. The results of a theoretical analysis of the prevailing reactions and some experimental crack healing studies are described below. The results clearly demonstrate that $\mathrm{TiC}$ is a potentially attractive healing agent for alumina matrices.

\section{Theoretical analysis of the healing potential of $\mathrm{TiC}$ in an alumina matrix}

In a recent publication Farle et al. [30] presented a theoretical frame work to predict the (intrinsic) healing ability of 59 metallo-ceramics on the basis of a number of fundamental physical parameters such as the thermal stability in an oxidative environment, the diffusion kinetics, the 
volume expansion upon oxidation, the work of adhesion between the reaction product and the matrix material and the CTE and modulus of the reaction product in relation to that of the parent phase. The first four parameters give information on the potential crack filling behaviour while the two latter parameters give information on the quality of the mechanical properties of healed cracks upon re-loading. In the present analysis we follow their analysis but focus on the properties relevant for extrinsic self-healing systems based on embedded granular healing particles.

\subsection{Thermodynamic stability of TiC}

The thermodynamic stability of $\mathrm{TiC}$ in the presence of oxygen and that of its intended reaction product $\mathrm{TiO}_{2}$ in the presence of $\mathrm{Al}_{2} \mathrm{O}_{3}$ is calculated using FACTSAGE (CRCT-ThermFACT Inc. \& GTT-Technologies). In Figure 1 the thermodynamic stability of TiC in air as a function of temperature is shown. The figure shows that thermodynamically speaking $\mathrm{TiC}$ can transform into $\mathrm{TiO}_{2}$ even at room temperature.

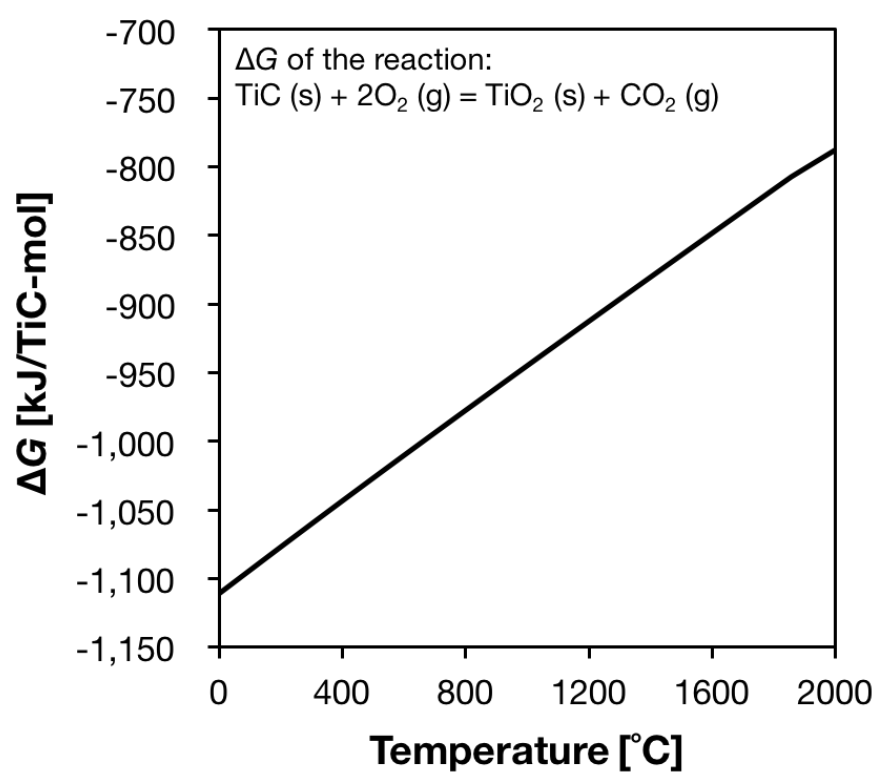


The calculated phase diagram for the $\mathrm{TiO}_{2}$ and $\mathrm{Al}_{2} \mathrm{O}_{3}$ system is shown in Figure 2 for the temperature window $1000-2000{ }^{\circ} \mathrm{C}$. This figure shows that there are no deep eutectica and that the lowest temperature at which a liquid phase is present is about $1700{ }^{\circ} \mathrm{C}$. Hence, this temperature sets the upper healing temperature ever to be considered for this system.

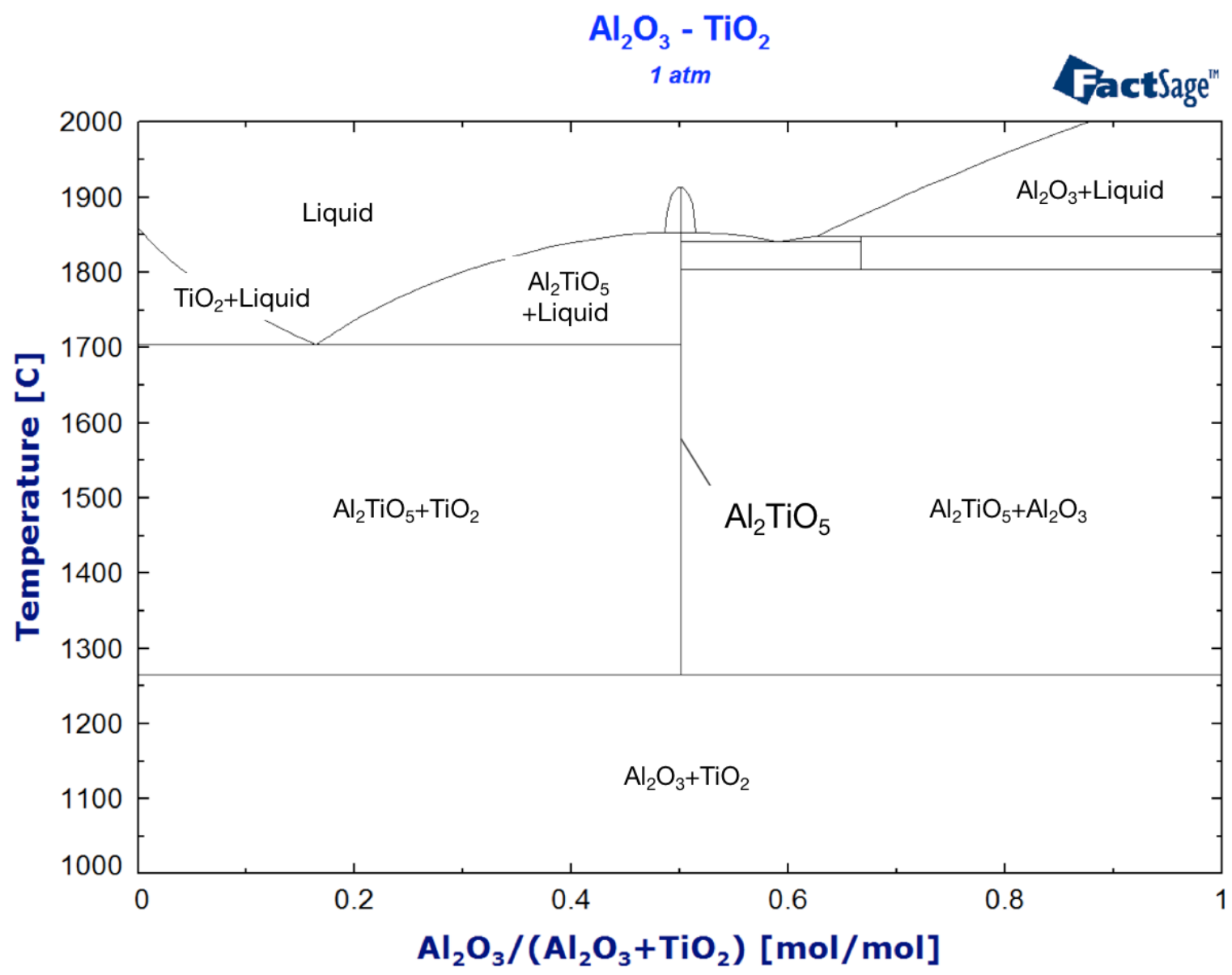

Figure $2 \mathrm{TiO}_{2}-\mathrm{Al}_{2} \mathrm{O}_{3}$ pseudo phase diagram (i.e. excluding oxides $\mathrm{TiO}_{2}-\mathrm{x}_{1} \mathrm{Ti}_{3} \mathrm{O}_{5}, \mathrm{Ti}_{2} \mathrm{O}_{3}, \mathrm{TiO}$ ).

According to the phase diagram, at temperatures between $1270{ }^{\circ} \mathrm{C}$ and $1800{ }^{\circ} \mathrm{C} \mathrm{TiO}$ can react with 
$\mathrm{Al}_{2} \mathrm{O}_{3}$ and form the intermediate compound $\mathrm{Al}_{2} \mathrm{TiO}_{5}$. This reaction product resembles the mullite formed in the $\mathrm{SiO}_{2}-\mathrm{Al}_{2} \mathrm{O}_{3}$ system. There are no reports on the reaction between $\mathrm{SiO}_{2}$ and the alumina matrix formation so that the formation of mullite at the crack-healed can be assumed to be quite slow or even absent. We postulate that this also applies to the $\mathrm{Al}_{2} \mathrm{TiO}_{5}$ compound. So provided the healing time is not too long, the temperature window $1270-1600{ }^{\circ} \mathrm{C}$ could be available for self-healing reactions. Based on the pseudo phase diagram, there are no further reactions between $\mathrm{TiO}_{2}$ and $\mathrm{Al}_{2} \mathrm{O}_{3}$ below $1270{ }^{\circ} \mathrm{C}$ and this indicates that provided all other conditions are met, the temperature domain below $1270{ }^{\circ} \mathrm{C}$ is suitable for self-healing reactions and prolonged material use.

\subsection{Relative volume expansion (RVE)}

Successful crack filing due to solid state chemical reactions requires that the molar volume of the reaction product is larger than that of the starting healing material in order to i) (fully or partially) fill the crack, ii) locally reconnect opposing crack faces and iii) re-establish mechanical integrity. The volumetric growth is expressed as the relative volume expansion (RVE). In this work we look at the decomposition of a carbide into a metallic oxide as presented by the following reaction:

$$
\mathrm{MC}+2 \mathrm{O}_{2}=\mathrm{MO}_{2}+\mathrm{CO}_{2} \uparrow
$$

Hence,

$$
\operatorname{RVE}[\%]=\frac{V_{\mathrm{MO}_{2}}-V_{\mathrm{MC}}}{V_{\mathrm{MC}}} \times 100
$$

Here, $V_{x}$ means molar volume of substance $X$. The value of $V_{x}$ can be calculated based on the following equation: 


$$
V_{\mathrm{x}}\left[\mathrm{cm}^{3} / \mathrm{mol}\right]=\frac{C[\dot{\mathrm{A}}] \times 10^{-24}}{N[-]} \times N_{A}\left[\mathrm{~mol}^{-1}\right]
$$

Here, $C$ means the cell volume of substance $X$ and $N$ means the number of unit in each cell. The crystal data used are listed in Table 1.

Table 1 Reference data used for RVE calculation.

\begin{tabular}{ccccc}
\hline Compound & $\begin{array}{c}\text { Cell Volume } \\
C\left[\AA^{3}\right]\end{array}$ & $\begin{array}{c}\text { Unit number } \\
N[-]\end{array}$ & $\begin{array}{c}\text { Molar volume } \\
\text { Vx [cm } 3 / \mathrm{mol}]\end{array}$ & $\begin{array}{c}\text { Reference } \\
\text { (PDF No.) }\end{array}$ \\
\hline $\mathrm{SiC}$ & 82.77 & 4 & 12.5 & $01-075-0254$ \\
$\mathrm{TiC}$ & 81.07 & 4 & 12.2 & $04-004-2919$ \\
$\mathrm{SiO}_{2}($ Cristobalite) & 176.54 & 4 & 26.6 & $01-082-0512$ \\
$\mathrm{TiO}_{2}$ (Rutile) & 62.43 & 2 & 18.8 & $00-021-1276$ \\
\hline
\end{tabular}

The calculated RVE of TiC is shown in Table 2. As seen in Table 2, the RVE of TiC is more than $0 \%$, which means that TiC can indeed create the extra volume required for filling the crack-gap upon oxidation.

Table 2 Calculated RVE value of TiC and SiC.

\begin{tabular}{cc}
\hline Reaction & Relative Volume Expansion (RVE) [\%] \\
\hline $\mathrm{SiC}+2 \mathrm{O}_{2} \rightarrow \mathrm{SiO}_{2}$ (Cristobalite) $+\mathrm{CO}_{2}$ & 113.3 \\
$\mathrm{TiC}+2 \mathrm{O}_{2} \rightarrow \mathrm{TiO}_{2}$ (Rutile) $+\mathrm{CO}_{2}$ & 54.0 \\
\hline
\end{tabular}

According to previous studies [3-4], 15 vol.\% fraction of SiC was sufficient for filling the surface crack with $100 \mu \mathrm{m}$ and attain full strength recovery of alumina/ SiC composite. Assuming the local crack 


\subsection{Work of adhesion}

In order to achieve complete strength recovery, the energy required to separate the crack-filling oxide from the alumina matrix should be comparable or greater than the cohesion strength of the alumina matrix. This adhesion energy of the interface between matrix/ crack-filling oxide interface is defined as the 'work of adhesion'. This work of adhesion can be expressed by [35]:

$$
W_{\mathrm{ad}}=-\left(\gamma_{\text {matrix }}^{\text {surf }}+\gamma_{\text {oxide }}^{\text {surf }}\right)+\gamma_{\text {matrix } / \text { oxide }}^{\text {interface }}
$$

where, $\gamma_{\text {matrix }}^{\text {surf }}$ and $\gamma_{\text {oxide }}^{\text {surf }}$ mean the surface energy of matrix and oxide, and $\gamma_{\text {matrix/oxide }}^{\text {interface }}$ means the interface energy between matrix/ crack-filling oxide interface. The value for the interface energy has been estimated from the interaction energies of the atoms located at each site of the interface [36, 37]. The interaction energies were calculated from solution enthalpies of an element at one site of interface dissolved in another element at the other site of the interface. Details of the calculations can be found elsewhere [38].

The calculated work of adhesion for relevant interfaces are shown in Figure 3. 


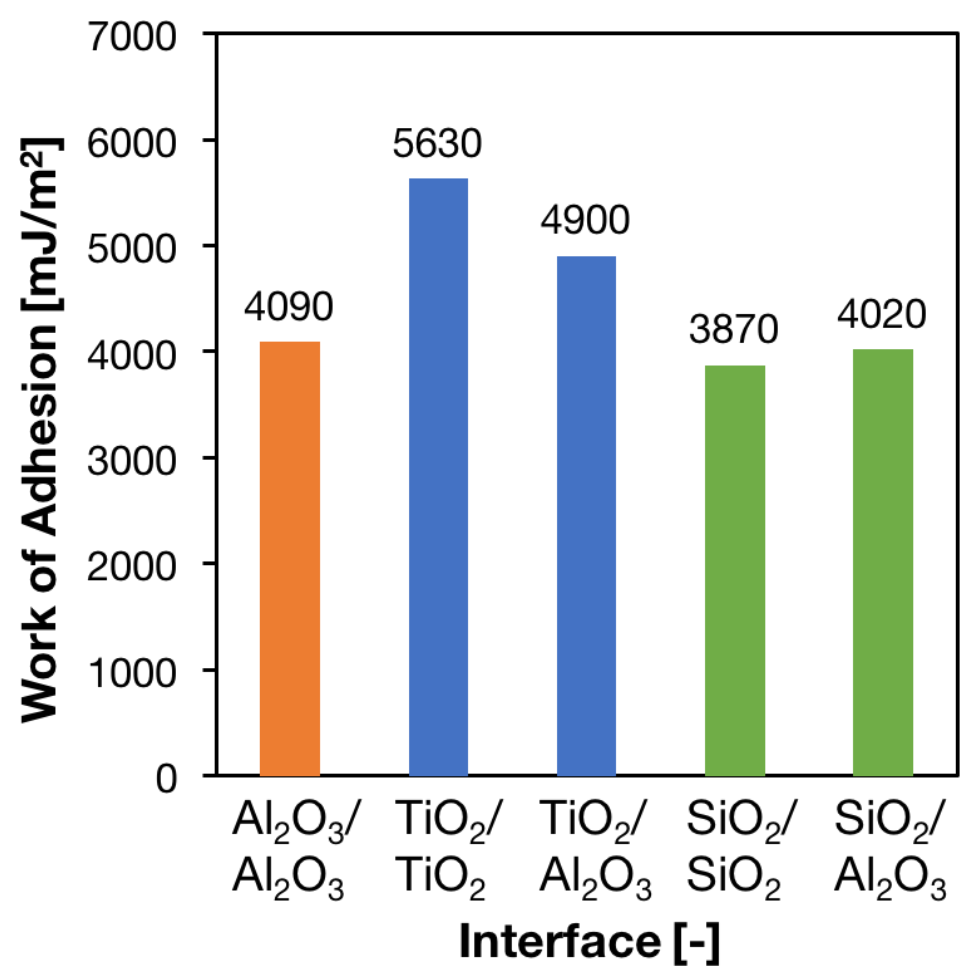

Figure 3 Calculated works of adhesion for relevant interfaces.

As justified in Section 2.1, in the present analysis the formation of $\mathrm{Al}_{2} \mathrm{TiO}_{5}$ is ignored. The work of adhesion for the $\mathrm{Al}_{2} \mathrm{O}_{3} / \mathrm{TiO}_{2}$ interface $\left(4900 \mathrm{~mJ} / \mathrm{m}^{2}\right)$ and that for the $\mathrm{TiO}_{2} / \mathrm{TiO}_{2}$ interface $(5630$ $\left.\mathrm{mJ} / \mathrm{m}^{2}\right)$ are greater than that for the $\mathrm{Al}_{2} \mathrm{O}_{3} / \mathrm{Al}_{2} \mathrm{O}_{3}$ interface $\left(4090 \mathrm{~mJ} / \mathrm{m}^{2}\right)$. The latter two values represent the cohesion of the crack filling and matrix phase, respectively. It means that the crack-healed part in alumina/ TiC could be stronger than the alumina matrix itself. To put these values in perspective we also report the work of adhesion between $\mathrm{Al}_{2} \mathrm{O}_{3} / \mathrm{SiO}_{2}$ interface $\left(4020 \mathrm{~mJ} / \mathrm{m}^{2}\right)$ which is a well-known self-healing ceramic system.

From these calculations, it can be postulated that the alumina/ TiC composites will attain full strength recovery once the crack is filled up adequately with the $\mathrm{TiO}_{2}$ formed. 


\subsection{Comparison of the thermal expansion coefficients}

Even if the crack is fully filled by the formation of an oxidic phase at the healing temperature, this is no guarantee that a strong and reliable bond is formed when the sample is exposed to a wide range of temperatures. Differences in coefficient of thermal expansion (CTE) between the matrix and the material formed in the crack as a result of the healing reaction may lead to local stresses. Hence, it is important to compare the CTE's of matrix $\left(\mathrm{Al}_{2} \mathrm{O}_{3}\right)$, healing agent $(\mathrm{TiC})$ and crack-filling oxides $\left(\mathrm{TiO}_{2}\right)$. Relevant average CTE values are listed in Table 3, together with the related values for alumina /SiC composites. The dependence of CTE on crystal orientation was not taken into account as the material deposited in the crack is polycrystalline.

Table 3 Thermal expansion coefficients of relevant compounds in alumina /TiC and alumina/ SiC composite.

\begin{tabular}{cccc}
\hline Compound & Temperature Range $\left[{ }^{\circ} \mathrm{C}\right]$ & $\mathrm{CTE} \times 10^{-6}\left[{ }^{\circ} \mathrm{C}^{-1}\right]$ & Reference \\
\hline \multirow{2}{*}{$\mathrm{Al}_{2} \mathrm{O}_{3}$} & $1000-1600$ & $7.5 \pm 0.4$ & {$[39]$} \\
& $20-2025$ & $7.3-8.3$ & {$[40]$} \\
$\mathrm{TiC}$ & $23-848$ & $6.99 \pm 0.34-7.61 \pm 0.20$ & {$[41]$} \\
& $1000-2600$ & $8.31 \pm 0.68$ & {$[39]$} \\
$\mathrm{SiC}$ & $25-1000$ & $3.2-5.1$ & {$[42]$} \\
& $1000-1600$ & $5.68 \pm 0.11$ & {$[39]$} \\
$\mathrm{TiO}_{2}$ (rutile) & $30-650$ & $7.249-8.816$ & {$[43]$} \\
& $20-1610$ & $8.9-11.1$ & {$[40]$} \\
$\mathrm{SiO}_{2}$ (Cristobalite) & $100-500$ & 10.9 & {$[44]$} \\
& $500-1000$ & 1.7 & {$[44]$} \\
\hline
\end{tabular}

According to Table 3, the CTE values of the matrix, the unreacted healing agent and the 
relevant crack-filling oxides in the alumina / TiC system considered are in the range of $6.65 \times 10^{-6}$ to $11.1 \times 10^{-6}\left[{ }^{\circ} \mathrm{C}^{-1}\right]$. The maximum mismatch value is $4.45 \times 10^{-6}\left[{ }^{\circ} \mathrm{C}^{-1}\right]$ between $\mathrm{TiC}$ and $\mathrm{TiO}_{2}$ at temperature region from room temperature to $500{ }^{\circ} \mathrm{C}$. In contrast, the maximum mismatch value in the reference alumina $/ \mathrm{SiC}$ system is $7.7 \times 10^{-6}\left[{ }^{\circ} \mathrm{C}^{-1}\right]$ between $\mathrm{SiC}$ and $\mathrm{SiO}_{2}$ at temperature region from room temperature to $500{ }^{\circ} \mathrm{C}$, and $6.6 \times 10^{-6}\left[{ }^{\circ} \mathrm{C}^{-1}\right]$ between alumina matrix and $\mathrm{SiO}_{2}$ at above $500{ }^{\circ} \mathrm{C}$. Considering there are no reports on the spontaneous fracture of alumina /SiC self-healing ceramics due to thermal expansion mismatch, it can be proposed that the effects of the CTE mismatch in the alumina /TiC composites on structural integrity can be ignored at this stage.

\subsection{Comparison of the elastic properties}

A healed crack in a ceramic compound may not only be exposed to the thermal stresses induced by temperature excursions but may also be exposed to mechanical stresses due to external loading. In this case it is important to compare the elastic moduli of the matrix, the healing agent and the decomposition product. The Young's moduli of relevant (polycrystalline) compounds in alumina /TiC and alumina/ SiC composites are listed in Table 4.

Table 4 Young' modulus of related compounds in alumina /TiC and alumina/ SiC composite. 


\begin{tabular}{ccccc}
\hline Compound & Specimen & Density [-] & Young's modulus [GPa] & Reference \\
\hline & Sintered bulk & $\geq 99.6$ & $380-410$ & {$[45]$} \\
& Sintered bulk & $\geq 99.8$ & $380-405$ & {$[45]$} \\
$\mathrm{Al}_{2} \mathrm{O}_{3}$ & Sintered bulk & $\geq 99.5$ & $398-400$ & {$[45]$} \\
& Sintered bulk & $\geq 99.6$ & $340-380$ & {$[45]$} \\
& Sintered bulk & $\geq 99.0$ & $340-380$ & {$[45]$} \\
$\mathrm{TiC}_{x}(x<1)$ & Thin firm & - & $<460$ & {$[46]$} \\
$\mathrm{SiC}$ & Sintered bulk & $\geq 0.98$ & 415 & {$[47]$} \\
$\mathrm{TiO}_{2}$ & Cristalized thin firm & - & 85 & {$[48]$} \\
$\mathrm{SiO}_{2}$ (Cristobalite) & Natural single crystal & - & 65.2 & {$[49]$} \\
\hline
\end{tabular}

Considering that Young's modulus of $\mathrm{TiC}_{\mathrm{x}}$ is depends on the carbon level [46], it can be stated that the Young's modulus of $\mathrm{TiC}_{\mathrm{x}}$ is more or less comparable to alumina matrix, as is the case for $\mathrm{SiC}$. In contrast, the modulus of $\mathrm{SiO}_{2}$ and $\mathrm{TiO}_{2}$ is considerable lower than that of matrix. Based on the values reported and given that full strength recovery has been attained in alumina/ SiC system, it is expected that the alumina/ TiC can also yield comparable self-healing levels. Early cracking along the healed interface is not very likely to occur unless at higher macroscopic stress levels.

In conclusion, based on the theoretical analysis presented above it is to be expected that autonomous high-temperature oxidative healing of the mechanical integrity of an $\mathrm{Al}_{2} \mathrm{O}_{3}$ composites filled with (10-30 vol \%) TiC particles should theoretically be possible.

\section{Experimental}

Alumina matrix composites containing 15 vol.\% TiC and 30 vol.\% TiC, named Al15TiC and 
Al30TiC respectively, were prepared and their strength recovery at room temperature as a function of the healing temperature was studied under the conditions specified below. Furthermore, the microstructural changes responsible for the strength recovery were also determined.

\subsection{Sample preparation}

Alumina raw powder (AKP-50, Sumitomo Chemical Co., Ltd.), and TiC powder (STD120, H.C.

Starck $\mathrm{GmbH}$ ) were used as starting materials. The initial average sizes were 0.2 and $2 \mu \mathrm{m}$, respectively.

Ball-milling of TiC powder was conducted for $36 \mathrm{~h}$ in isopropanol with ø10 $\mathrm{mm}$ WC ball and a WC jar, resulting in an average particle size of $0.3 \mu \mathrm{m}$. Alumina powder and ball-milled TiC powder were mixed at either 15 vol.\% or 30 vol.\% in isopropanol using $\varnothing 5 \mathrm{~mm}$ alumina balls and a $1000 \mathrm{ml}$ plastic bottle. After $12 \mathrm{~h}$ mixing, the mixed powder was dried in the oven for $24 \mathrm{~h}$ at $80{ }^{\circ} \mathrm{C}$. The dried powder was sieved with a $\varnothing 200 \mu \mathrm{m}$ mesh powder sieve. The sieved powder was densified by means of spark plasma sintering (HP D 25-SD furnace, FCT Systeme $\mathrm{GmbH}$ ) with a $\varnothing 40 \mathrm{~mm}$ carbon mould at $1500^{\circ} \mathrm{C}$ for $15 \mathrm{~min}$. in vacuum condition under $35 \mathrm{MPa}$. The heating rate was $10^{\circ} \mathrm{C} / \mathrm{min}$ while natural cooling was used to cool down from the maximum temperature. The typical thickness of the samples was about $5 \mathrm{~mm}$. The relative density of the sintered bulk materials as measured by Archimedes' method was more than $99 \%$. The sintered discs were cut into rectangular samples with a dimension of $3 \times 4$ x $23 \mathrm{~mm}$ for four-point bending tests. Samples were polished in various steps with a final polish using a diamond paste with a particle size of $0.25 \mu \mathrm{m}$. 


\subsection{Strength recovery tests}

In order to study the strength recovery of A15TiC and Al30TiC as a function of the annealing temperature, the strength values of three types of specimen (smooth specimen, pre-cracked specimen and healed specimen), were determined. Smooth specimen refers to samples without any induced damage prior to testing. Pre-cracked specimen are specimen with a standardized pre-crack at the centre of the surface introduced by Vickers' indenter. The indentation force was $20 \mathrm{~N}$ and the introduced crack had a surface length of about $100 \mu \mathrm{m}$ for both sets of samples. The surface crack opening distance of these cracks could not be established with any real accuracy but was estimated to vary between 0.1 to $0.5 \mu \mathrm{m}$. The two sets of radial indentation cracks are either perpendicular or parallel to the longest dimension of the bend test samples. No strong interaction between the indentation induced radial cracks and the healing particles was observed. The healed specimens are pre-cracked and have been annealed for $1 \mathrm{~h}$ in air at temperatures ranging from 400 to $1000{ }^{\circ} \mathrm{C}$.

The strength of each sample was measured by means of an auto aligning four-point bending test using the set-up shown in Figure 4. 


\subsection{Structure characterisation}

The external appearance of the healed cracks was recorded with a laser microscope (KEYENCE,

VK-X) and analysed using image software. The chemical composition of the reaction product formed in the crack was determined using Electron Probe Micro Analysis (EPMA) using a JXA-8530F JEOL Ltd microprobe. To enable such measurements, the surface oxidation layer was removed by using a focused ion beam (JIB-4501, JEOL Ltd.). The crystal structure of the various phases in the samples prior and after thermal annealing was determined using XRD (ULTIMA IV, Rigaku Co.) operated with 
$\mathrm{CuK}_{\alpha}$ radiation.

\section{Results and Discussion}

\subsection{Strength recovery}

The results of strength recovery tests for both Al15TiC and Al30TiC are shown in Figure 5.

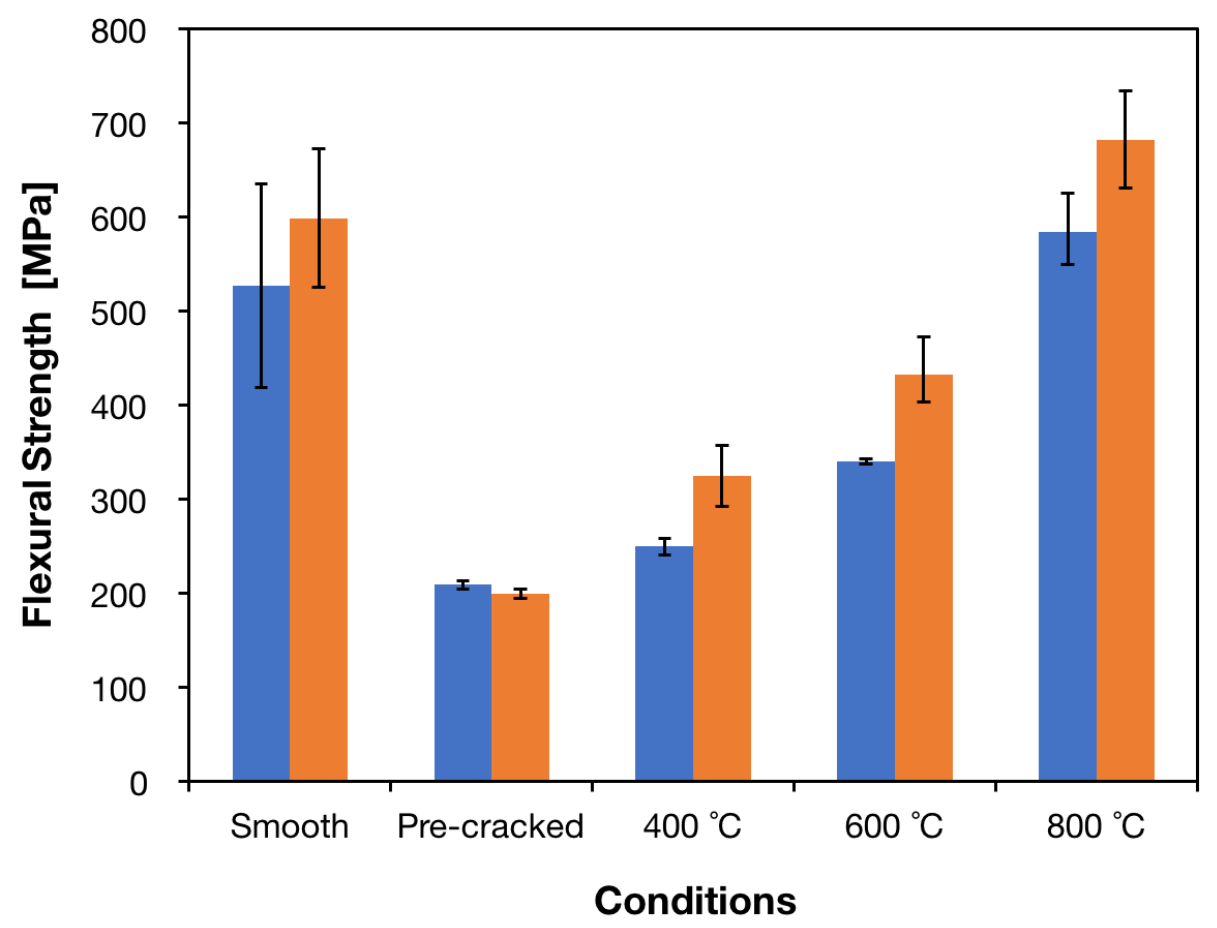

Figure 5 Flexural strength values of Al15TiC and Al30TiC samples after healing for $1 \mathrm{~h}$ in air at the reported temperature.

The averaged strength of smooth specimens at room temperature was $526 \mathrm{MPa}$ for Al15TiC and $598 \mathrm{MPa}$ for Al30TiC. The averaged strength of pre-cracked specimens was $208 \mathrm{MPa}$ for Al15TiC and $199 \mathrm{MPa}$ for Al30TiC., i.e. more or less equal and in accordance with the equal dimensions of the indentation induced cracks. Figure 5 shows that annealing at $400{ }^{\circ} \mathrm{C}$ already leads to some recovery 
of the strength (this could be due to oxidative healing but thermal blunting of the crack tip may also play a role). This lowest temperature at which partial strength recovery is observed is considerable lower than that observed for alumina/ $\mathrm{SiC}$ composites. Annealing at $800^{\circ} \mathrm{C}$ led to a complete recovery of the strength for both sets of samples.

\subsection{Microstructural observations}

Laser microscope images of pre-cracked area before and after annealed at each condition are shown in Fig. 6-8 for annealing temperatures of 400,600 and $800{ }^{\circ} \mathrm{C}$ respectively.
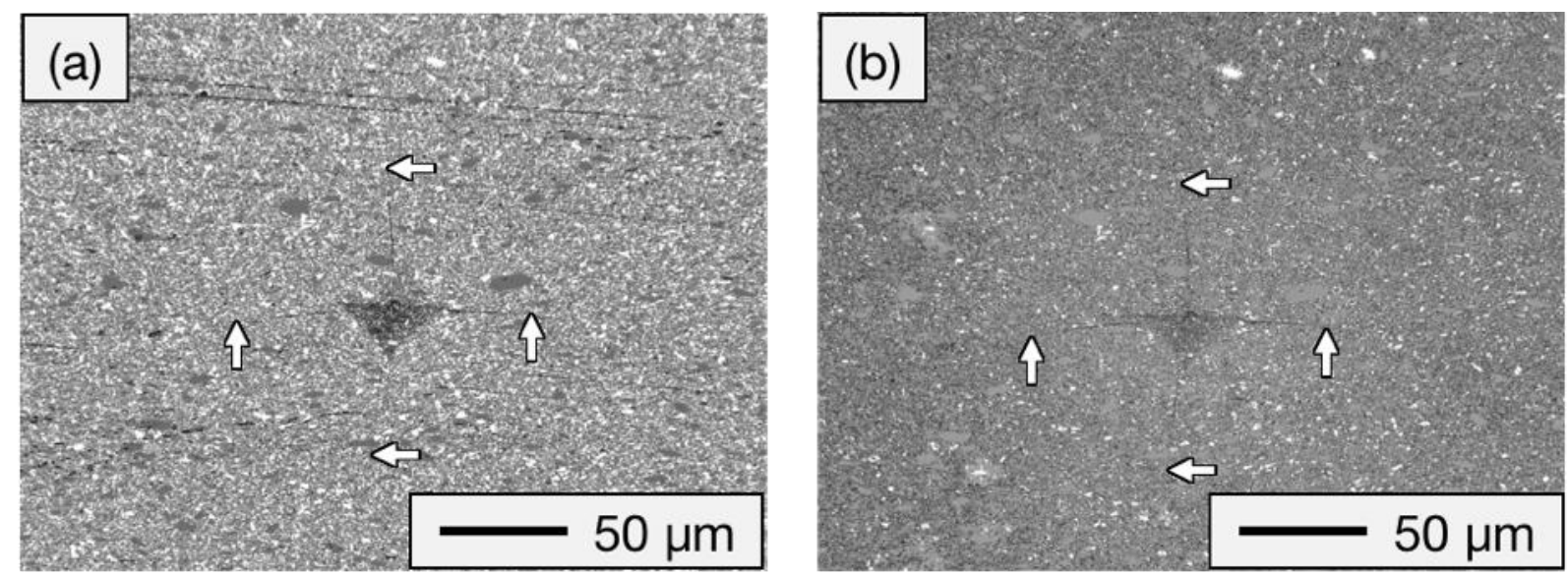

Fig. 6 Laser microscope image of pre-cracked area of Al30TiC (a) before annealing (b) after annealing at $400{ }^{\circ} \mathrm{C}$ for $1 \mathrm{~h}$. Arrows indicate the end-points of the radial cracks. 


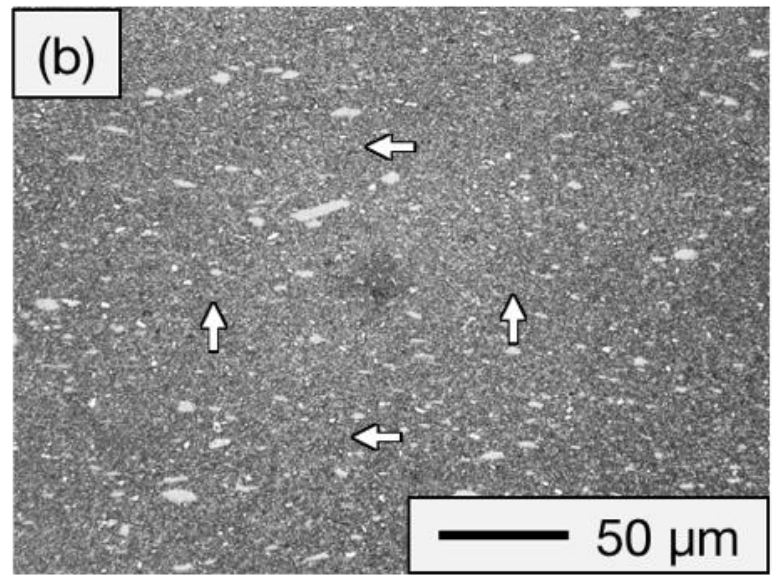

Fig. 7 Laser microscope image of pre-cracked area of Al30TiC (a) before annealing (b) after annealing at $600{ }^{\circ} \mathrm{C}$ for $1 \mathrm{~h}$. Arrows indicate the end-points of the radial cracks.
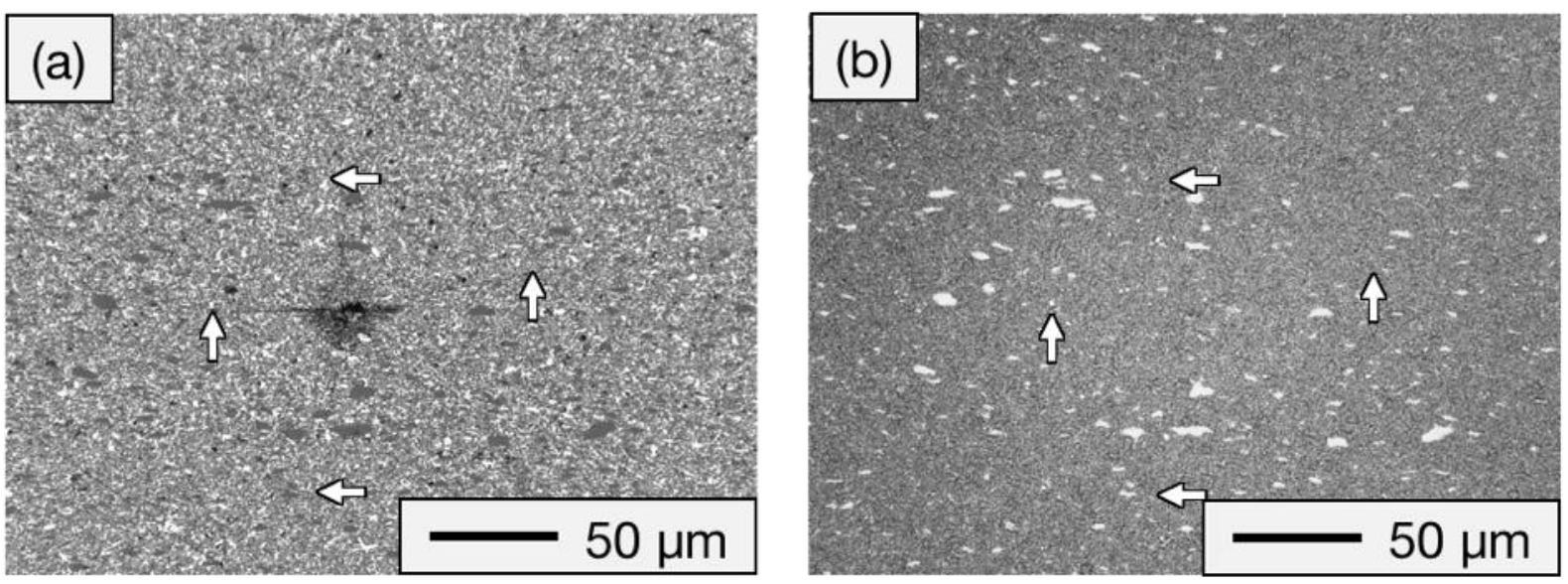

Fig. 8 Laser microscope image of pre-cracked area of AI30TiC (a) before annealing (b) after annealing at $800{ }^{\circ} \mathrm{C}$ for $1 \mathrm{~h}$. Arrows indicate the end-points of the radial cracks.

Figure 6 (sample annealed at $400{ }^{\circ} \mathrm{C}$ ) shows no sign of surface oxidation and the cracks

remain nicely visible. In contrast, Figures 7-8 (annealing temperatures 600 and $800{ }^{\circ} \mathrm{C}$, respectively) show clear signs of surface oxidation at the location of the TiC particles intercepting the external 
surface and the crack is no longer discernible.

Figure 9 shows the SEM image and backscattered electron image around the healed-crack area of the healed specimen at $800{ }^{\circ} \mathrm{C}$ for $1 \mathrm{~h}$ after removing the surface oxidation layer by mechanical polishing using $0.25 \mu \mathrm{m}$ diamond past. The healed crack is indicated by arrows in both figures. Taking the result of Energy Dispersive X-ray Spectrometry into account, it is clear that the crack is fully filled with the titanium oxide formed. It is interesting to note that the titanium oxide can be found also at locations in the crack well away from intersected TiC particles. This lateral spreading of the oxide along the crack is very advantageous for the healing efficiency. It also should be noticed that TiC healing-agent particles nearby the crack surface are still intact. In conclusion: Figure 9 confirms that the crack is fully filled up with titanium oxide upon $800{ }^{\circ} \mathrm{C}$ annealing for 1 hour.
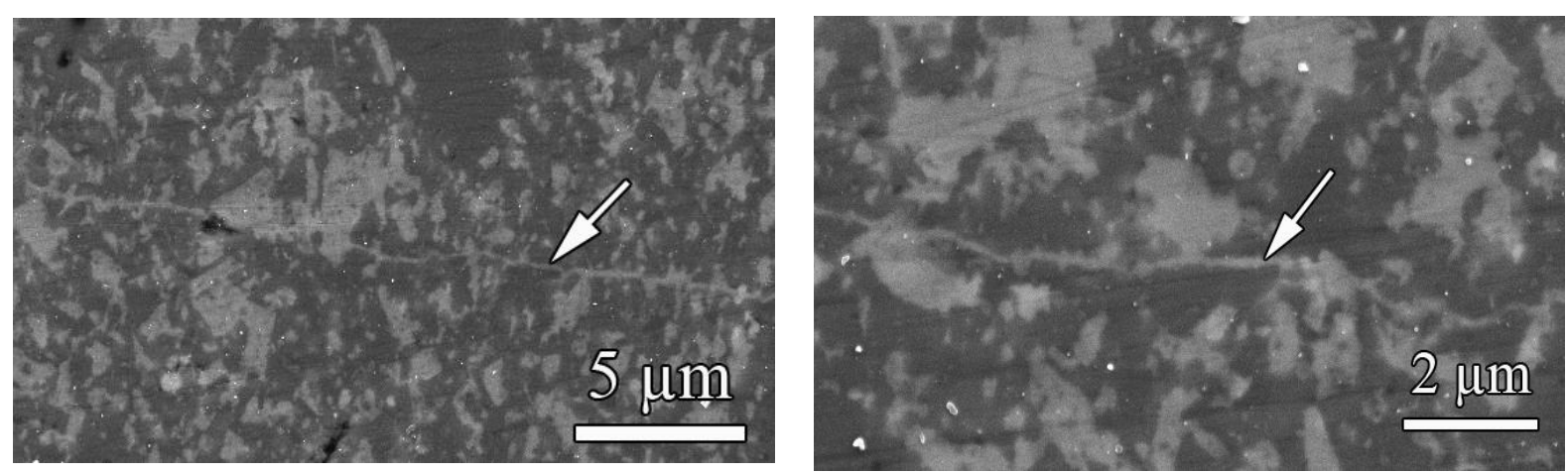

Fig. 9 Backscattered electron image of healed- crack area of Al30TiC annealed at $800{ }^{\circ} \mathrm{C}$ for $1 \mathrm{~h}$. The external oxidation layer was removed by minimal mechanical polishing. 
The results of XRD analysis of the as-synthesized and the annealed samples are shown in Figure 10. Some contamination of TiC with WC was expected due to the ball milling treatment, but no traces of WC were detected. The diffractogram after $1 \mathrm{~h}$ annealing at $400{ }^{\circ} \mathrm{C}$ did not differ from that of the as-synthesized specimen. For higher annealing temperatures clear signs of Rutile were observed, but Anatase and Brookite were not detected. TiC was still detectable in the sample annealed at $800{ }^{\circ} \mathrm{C}$. This indicates that the surface is not fully covered with $\mathrm{TiO}_{2}$ yet and also $\mathrm{TiC}$ is still intact nearby the surface. Also, the formation of $\mathrm{Al}_{2} \mathrm{TiO}_{5}$ was not detected even annealing at $800{ }^{\circ} \mathrm{C}$. Those results correspond to the discussion on the surface observations shown above and the possibility of $\mathrm{Al}_{2} \mathrm{TiO}_{5}$ formation during annealing at high temperatures in section 2.1. 


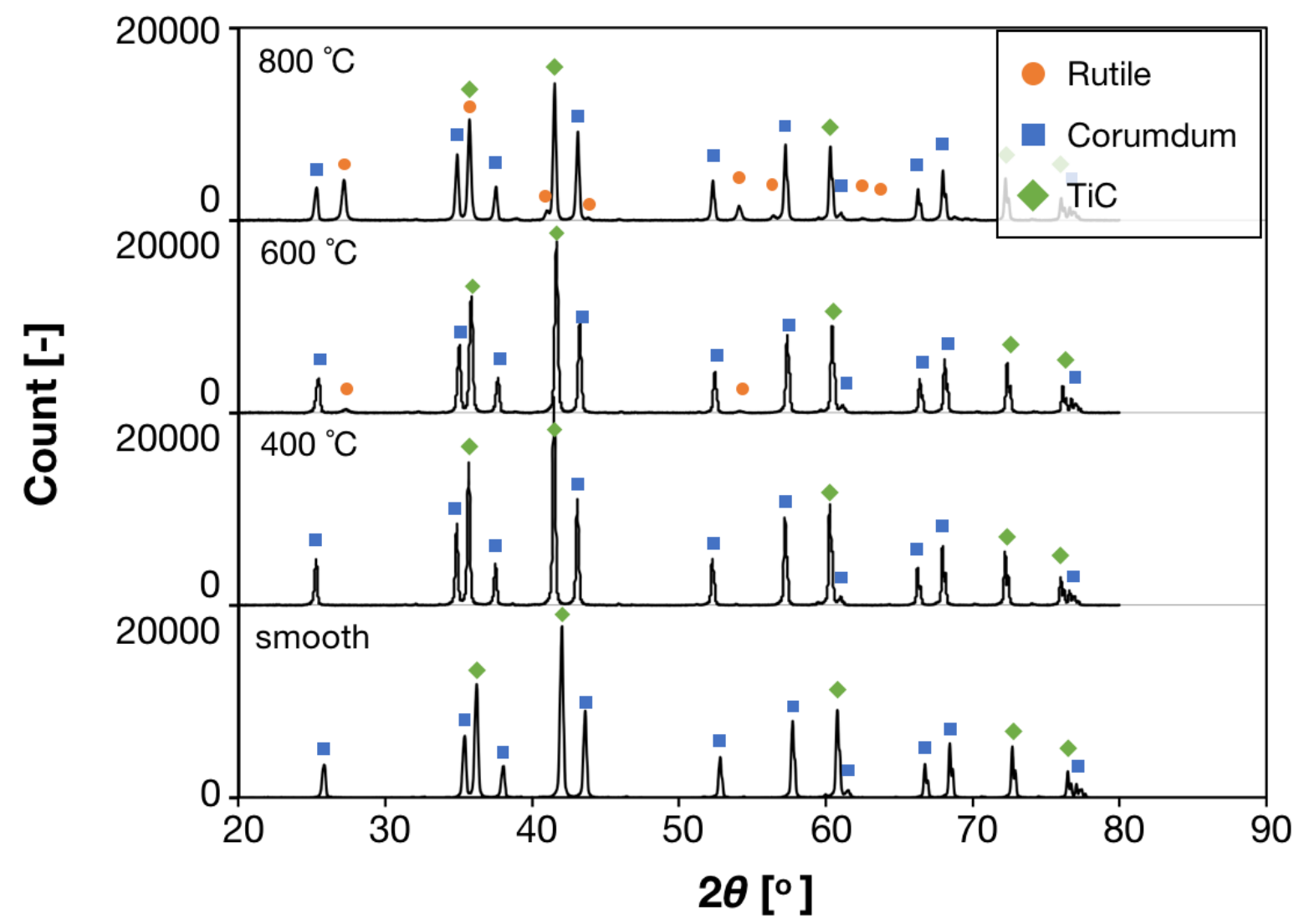

Fig. 10 XRD patterns of Al30TiC in the pristine state (smooth) and after annealing for $1 \mathrm{~h}$ at the

temperatures indicated.

Finally, it should be mentioned that at $800{ }^{\circ} \mathrm{C}$ full strength recovery was observed for both A15TiC and Al30TiC material while it was postulated on the basis of the RVE calculations that in the case of 15 vol.\% TiC (i.e. Al15TiC material) the additional volume created by the oxidation of 15 vol.\% TiC might be insufficient to fully fill and heal the cracks. Clearly the critical volume concentration for full crack filling depends not only on the length of the crack but also on the average local crack facing distance (i.e. the total initial open crack volume). [50]. The full healing of the Al15TiC material may well be attributable to either more narrow indentation cracks than assumed or easier long-range transport 
of the $\mathrm{Ti}$ atoms along the crack and through the matrix. Complicated $4 \mathrm{D}$ nano-CT tomography measurements of the type reported elsewhere for high temperature crack healing in MAX phase material [51] would be required to establish the degree of crack filling in this material also below the surface.

\section{Conclusion}

This paper aimed to study the capability of $\mathrm{TiO}_{2}$ as a crack-filling oxide for self-healing oxidic ceramics and the self-healing property of alumina/ TiC composites in particular. A detailed theoretical analysis of the healing reaction and the intrinsic properties of the reaction products revealed that TiC is indeed a potentially attractive healing agent for extrinsic self-healing ceramic systems. Experimental studies on SPS sintered $\mathrm{Al}_{2} \mathrm{O}_{3}$-TiC composites containing 15 and 30 vol\% TiC particles with a typical diameter of $0.3-5 \mu \mathrm{m}$ showed complete tensile strength recovery by annealing for $1 \mathrm{~h}$ at $800{ }^{\circ} \mathrm{C}$. The nature of the healing reactions was studied experimentally and found to be in accordance with the predicted complete filling of the indentation induced cracks via Rutile formation.

\section{Acknowledgement}

This research was sponsored by the People Program (Marie Curie ITN) of the European Union's seventh framework program under grant no. 290308 (SHeMat) and the Strategic Young Researcher Overseas Visits Program for Accelerating Brain Circulation of Japan Society for the Promotion of 
Science (JSPS) under grant no. R2403, and Advanced Low Carbon Technology Research and

Development Program of Japan Science and Technology Agency (JST-ALCA).

\section{References}

[1] Thompson, A. M., Chan, H. M., Harmer, M. P., \& Cook, R. E. (1995). Crack healing and stress relaxation in $\mathrm{Al}_{2} \mathrm{O}_{3} \mathrm{SiC}$ " nanocomposites". Journal of the American Ceramic Society, 78(3), 567-571.

[2] Chou, I. A., Chan, H. M., \& Harmer, M. P. (1998). Effect of annealing environment on the crack healing and mechanical behavior of Silicon Carbide-reinforced alumina nanocomposites. Journal of the American Ceramic Society, 81(5), 1203-1208.

[3] Ando, K., Kim, B. S., Chu, M. C., Saito, S., \& Takahashi, K. (2004). Crack-healing and mechanical behaviour of $\mathrm{Al}_{2} \mathrm{O}_{3} / \mathrm{SiC}$ composites at elevated temperature. Fatigue \& Fracture of Engineering Materials \& Structures, 27(7), 533-541.

[4] Ono, M., Nakao, W., Takahashi, K., Nakatani, M., \& Ando, K. (2007). A new methodology to guarantee the structural integrity of $\mathrm{Al}_{2} \mathrm{O}_{3} / \mathrm{SiC}$ composite using crack healing and a proof test. Fatigue \& Fracture of Engineering Materials \& Structures, 30(7), 599-607.

[5] Osada, T., Nakao, W., Takahashi, K., \& Ando, K. (2009). Kinetics of Self-Crack-Healing of Alumina/Silicon Carbide Composite Including Oxygen Partial Pressure Effect. Journal of the American Ceramic Society, 92(4), 864-869. 
[6] Chu, M. C., Sato, S., Kobayashi, Y., \& Ando, K. (1995). Damage healing and strengthening behaviour in intelligent mullite/SiC ceramics. Fatigue \& Fracture of Engineering Materials \& Structures, 18(9), 1019-1029.

[7] Ando, K., Chu, M.-C., Tsuji, K., Hirasawa, T., Kobayashi, Y., \& Sato, S. (2002). Crack healing behaviour and high-temperature strength of mullite/SiC composite ceramics. Journal of the European Ceramic Society, 22(8), 1313-1319.

[8] Ando, K., Ikeda, T., Sato, S., Yao, F., \& Kobayasi, Y. (1998). A preliminary study on crack healing behaviour of $\mathrm{Si}_{3} \mathrm{~N}_{4} / \mathrm{SiC}$ composite ceramics. Fatigue \& Fracture of Engineering Materials \& Structures, 21(1), 119-122.

[9] Ando, K., Chu, M., Yao, F., \& Sato, S. (1999). Fatigue strength of crack-healed $\mathrm{Si}_{3} \mathrm{~N}_{4} / \mathrm{SiC}$ composite ceramics. Fatigue \& Fracture of Engineering Materials \& Structures, 22(10), 897-903.

[10] Houjou, K., Ando, K., \& Takahashi, K. (2010). Crack-healing behaviour of $\mathrm{ZrO}_{2} / \mathrm{SiC}$ composite ceramics. International Journal of Structural Integrity, 1(1), 73-84.

[11] Houjou, K., \& Takahashi, K. (2012). Crack-healing behavior of $\mathrm{ZrO}_{2} / \mathrm{SiC}$ composite ceramics and strength properties of crack-healing specimens. International Journal of Structural Integrity, 3(1), 41-52.

[12] Takahashi, K., Yokouchi, M., Lee, S. K., \& Ando, K. (2003). Crack- healing behavior of $\mathrm{Al}_{2} \mathrm{O}_{3}$ toughened by SiC whiskers. Journal of the American Ceramic Society, 86(12), 2143-2147. 
[13] Nakao, W., Ono, M., Lee, S.-K., Takahashi, K., \& Ando, K. (2005). Critical crack-healing condition for SiC whisker reinforced alumina under stress. Journal of the European Ceramic Society, 25(16), 3649-3655.

[14] Nakao, W., Mori, S., Nakamura, J., Takahashi, K., Ando, K., \& Yokouchi, M. (2006). Self-crack-healing behavior of Mullite/SiC particle/SiC Whisker multi-composites and potential use for ceramic springs. Journal of the American Ceramic Society, 89(4), $1352-1357$

[15] Takahashi, K., Uchiide, K., Kimura, Y., Nakao, W., Ando, K., \& Yokouchi, M. (2007). Threshold stress for crack healing of mullite reinforced by SiC whiskers and SiC particles and resultant fatigue strength at the healing temperature. Journal of the American Ceramic Society, 90(7), 2159-2164.

[16] Nakao, W., Tsutagawa, Y., \& Ando, K. (2008). Enhancement of in situ self-crack-healing efficient temperature region by SiC nanosizing. Journal of Intelligent Material Systems and Structures, 19(3), 407-410.

[17] Wataru, N., \& Shihomi, A. (2012). Enhancement of the self-healing ability in oxidation induced self-healing ceramic by modifying the healing agent. Smart Materials and Structures, 21(2), 025002.

[18] Abe, O., Ohwa, Y., \& Kuranobu, Y.-i. (2006). Possibility of enhanced strength and self-recovery of surface damages of ceramics composites under oxidative conditions. Journal of the European Ceramic Society, 26(4), 689-695. 
[19] Salas-Villaseñor, A. L., Lemus-Ruiz, J., Nanko, M., \& Maruoka, D. (2009). Crack disappearance by high-temperature oxidation of alumina toughened by Ni nano-particles. Advanced Materials Research, 68, 34-43.

[20] Maruoka, D., Sato, Y., \& Nanko, M. (2010). Crack-Healing Effectiveness of Nano Ni+ SiC Co-Dispersed Alumina Hybrid Materials. Advanced Materials Research. 89(91), 365-370.

[21] Maruoka, D., \& Nanko, M. (2013). Recovery of mechanical strength by surface crack disappearance via thermal oxidation for nano-Ni/ $\mathrm{Al}_{2} \mathrm{O}_{3}$ hybrid materials. Ceramics International, 39(3), 3221-3229.

[22] Yoshioka, S., \& Nakao, W. (2015). Methodology for evaluating self-healing agent of structural ceramics. Journal of Intelligent Material Systems and Structures, 26(11), 1395-1403.

[23] Bei, G. P., Pedimonte, B. J., Pezoldt, M., Ast, J., Fey, T., Goeken, M., \& Greil, P. (2015). Crack Healing in $\mathrm{Ti}_{2} \mathrm{Al}_{0.5} \mathrm{Sn}_{0.5} \mathrm{C}-\mathrm{Al}_{2} \mathrm{O}_{3}$ Composites. Journal of the American Ceramic Society, 98(5), 1604-1610.

[24] Song, G., Pei, Y., Sloof, W., Li, S., De Hosson, J. T. M., \& Van der Zwaag, S. (2008). Oxidation-induced crack healing in $\mathrm{Ti}_{3} \mathrm{AlC}_{2}$ ceramics. Scripta Materialia, 58(1), 13-16.

[25] Chen, G., Zhang, R., Zhang, X., Zhao, L., \& Han, W. (2009). Oxidation-induced crack healing in $\mathrm{Zr}_{2} \mathrm{Al}_{4} \mathrm{C}_{5}$ ceramic. Materials \& Design, 30(9), 3602-3607.

[26] Li, S., Song, G., Kwakernaak, K., van der Zwaag, S., \& Sloof, W. G. (2012). Multiple crack healing of a Ti 2 AIC ceramic. Journal of the European Ceramic Society, 32(8), 1813-1820. 
[27] Yang, H., Pei, Y., Rao, J., \& De Hosson, J. T. M. (2012). Self-healing performance of Ti ${ }_{2} A I C$ ceramic. Journal of Materials Chemistry, 22(17), 8304-8313.

[28] Li, S., Xiao, L., Song, G., Wu, X., Sloof, W. G., \& van der Zwaag, S. (2013). Oxidation and Crack Healing Behavior of a Fine-Grained $\mathrm{Cr}_{2} \mathrm{AlC}$ Ceramic. Journal of the American Ceramic Society, 96(3), 892-899.

[29] Yang, H., Pei, Y., \& De Hosson, J. T. M. (2013). Oxide-scale growth on $\mathrm{Cr}_{2} \mathrm{AlC}$ ceramic and its consequence for self-healing. Scripta Materialia, 69(2), 203-206.

[30] Farle, A.-S., Kwakernaak, C., van der Zwaag, S., \& Sloof, W. G. (2015). A conceptual study into the potential of $M_{n+1} A X_{n}$-phase ceramics for self-healing of crack damage. Journal of the European Ceramic Society, 35(1), 37-45.

[31] Li, S., Bei, G., Chen, X., Zhang, L., Zhou, Y., Mačković, M., Greil, P. (2016). Crack healing induced electrical and mechanical properties recovery in a $\mathrm{Ti}_{2} \mathrm{SnC}$ ceramic. Journal of the European Ceramic Society, 36(1), 25-32.

[32] Li, S., Li, H., Zhou, Y., \& Zhai, H. (2014). Mechanism for abnormal thermal shock behavior of $\mathrm{Cr}_{2}$ AlC. Journal of the European Ceramic Society, 34(5), 1083-1088.

[33] Van der Zwaag, S., Van Dijk, N., Jonkers, H., Mookhoek, S., \& Sloof, W. (2009). Self-healing behavior in man-made engineering materials: bioinspired but taking into account their intrinsic character. Philosophical Transactions of the Royal Society of London A: Mathematical, Physical and Engineering Sciences, 367(1894), 1689-1704. 
[34] Blaiszik, B., Kramer, S., Olugebefola, S., Moore, J. S., Sottos, N. R., \& White, S. R. (2010). Self-healing polymers and composites. Annual Review of Materials Research, 40, $179-211$

[35] Howe, J. (1993). Bonding, structure, and properties of metal/ceramic interfaces: Part 2 Interface fracture behaviour and property measurement. International materials reviews, 38(5), 257-271.

[36] Miedema, A., Niessen, A., De Boer, F., Boom, R., \& Matten, W. (1989). Cohesion in metals: transition metal alloys. Report, Philips Research Laboratories, Eindhoven, The Netherlands. FR de Boer, R. Boom, WCM Mattens, AR Miedema, AK Niessen: Cohesion in Metals. Transition Metals Alloys, North-Holland Publishing Co., Amsterdam.

[37] Vitos, L., Ruban, A., Skriver, H. L., \& Kollar, J. (1998). The surface energy of metals. Surface Science, 411(1), 186-202.

[38] Bennett, I. J., Kranenburg, J. M., \& Sloof, W. G. (2005). Modeling the Influence of Reactive Elements on the Work of Adhesion between Oxides and Metal Alloys. Journal of the American Ceramic Society, 88(8), 2209-2216.

[39] Engberg, C. J., \& Zehms, E. H. (1959). Thermal Expansion of $\mathrm{Al}_{2} \mathrm{O}_{3}, \mathrm{BeO}, \mathrm{MgO}, \mathrm{B}_{4} \mathrm{C}, \mathrm{SiC}$, and TiC Above $1000^{\circ} \mathrm{C}$. Journal of the American Ceramic Society, 42(6), 300-305.

[40] Fei, Y. (1995). Thermal expansion. Mineral physics and crystallography: a handbook of physical constants, 2, 29-44. 
[41] Elliott, R. O., \& Kempter, C. P. (1958). Thermal expansion of some transition metal carbides. The Journal of Physical Chemistry, 62(5), 630-631.

[42] Li, Z., \& Bradt, R. (1986). Thermal expansion of the cubic (3C) polytype of SiC. Journal of Materials Science, 21(12), 4366-4368.

[43] Rao, K. K., Naidu, S. N., \& lyengar, L. (1970). Thermal expansion of rutile and anatase. Journal of the American Ceramic Society, 53(3), 124-126.

[44] Aumento, F. (1966). Stability lattice parameters and thermal expansion of beta-cristobllite. American Mineralogist, 51(7), 1167-1175.

[45] Auerkari, P. (1996). Mechanical and physical properties of engineering alumina ceramics. Technical Research Centre of Finland Finland. (private communication)

[46] Török, E., Perry, A. J., Chollet, L., \& Sproul, W. D. (1987). Young's modulus of TiN, TiC, ZrN and HfN. Thin Solid Films, 153(1), 37-43.

[47] Munro, R. (1997). Material properties of a sintered $\alpha$-SiC. Journal of Physical and Chemical Reference Data, 26(5), 1195-1203.

[48] Olofinjana, A. O., Bell, J. M., \& Jämting, A. K. (2000). Evaluation of the mechanical properties of sol-gel-deposited titania films using ultra-micro-indentation method. Wear, 241(2), 174-179.

[49] de Faoite, D., Browne, D. J., Chang-Díaz, F. R., \& Stanton, K. T. (2012). A review of the processing, composition, and temperature-dependent mechanical and thermal 
properties of dielectric technical ceramics. Journal of Materials Science, 47(10), 4211-4235.

[50] Mookhoek, S. D., Fischer, H. R., \& van der Zwaag, S. (2009). A numerical study into the effects of elongated capsules on the healing efficiency of liquid-based systems. Computational Materials Science, 47(2), 506-511.

[51] Sloof, W. G., McDonald, S. A., Pei, R., Fife, J. L., Shen, L., Boatemaa, L., Farle, A.-S., Yan, K., Zhang, X., Van der Zwaag, S., Lee, P. D., \& Withers, P. J. (2016). "Repeated crack healing in MAX phase ceramics revealed by 4D in-situ Xray tomographic microscopy". Nature Scientific Report 6 (2016). 